\title{
Investor Behavior In Islamic Capital Markets: Study On Muslim Students
}

\author{
Irton Irton', Salihah Khairawati' ${ }^{2}$, Mu'tashim Billah Murtadlo ${ }^{3}$ \\ ${ }^{1}$ Accounting Departement Universitas Amikom Yogyakarta, Indonesia \\ 1,2Sharia Management Departement STEI Hamfara Yogyakarta, Indonesia \\ E-mail: ${ }^{1}$ irtonusman@gmail.com, ${ }^{2}$ skbhamfara@gmail.com, ${ }^{3}$ tashim.82@gmail.com
}

\begin{abstract}
The purpose of this research is to know the behavior of investors towards Islamic capital market. The research was conducted on several Muslim student respondents from several universities in Yogyakarta who invested in sharia capital markets. The type of data in this study is primary data obtained through in-depth interviews. The results showed that there are two investor characters among students namely risk seeker or risk taker and risk-averse. Respondents realized that investing in the capital market has potential benefits as well as potential risks. For investors, risk seeker has high confidence and optimism when making investment decisions, while risk-averse tends to be cautious and a lot of consideration when making investment decisions. In general, sharia capital market investors who are the majority of students have a good belief in the wisdom of stocks traded in sharia capital markets. They believe in the fatwa of scholars, the role of the DSN, and the role of capital market supervisory bodies. They are mostly also looking for information about sharia capital market sharia through books, capital market socialization, IDX web. In terms of transaction mechanisms in the sharia capital market only a small part still doubts its validity due to issue factors, lack of understanding of islamic capital market the correctness factor of the company's financial performance, and the ups and downs of the share price.
\end{abstract}

Keywords: investor behavior, investment decisions, sharia capital market

\begin{abstract}
ABSTRAK
Tujuan penelitian ini adalah untuk mengetahui perilaku investor terhadap pasar modal syariah. Penelitian dilakukan terhadap sejumlah responden mahasiswa muslim dari beberapa perguruan tinggi di Yogyakarta yang melakukan investasi di pasar modal syariah. Jenis data dalam penelitian ini adalah data primer yang diperoleh melalui wawancara Hasil penelitian menunjukkan bahwa terdapat dua karakter investor di kalangan mahasiswa yakni risk seeker atau risk taker dan risk averse. Responden menyadari bahwa investasi di pasar modal memiliki potensi untung dan juga potensi resiko. Bagi investor risk seeker memiliki rasa percaya diri yang tinggi dan optimis ketika mengambil keputusan investasi, sedangkan risk averse cenderung berhati-hati dan banyak pertimbangan ketika mengambil keputusan investasi. Secara umum investor pasar modal syariah yang merupakan mahasiswa mayoritas memiliki keyakinan yang baik mengenai kesyariahan saham-saham yang diperdagangkan di pasar modal syariah. Mereka percaya terhadap fatwa ulama, peranan DSN dan peranan badan pengawas pasar modal. Mereka sebagian besar juga mencari informasi tentang kesyariahan pasar modal syariah melalui buku, sosialisasi pasar modal, web IDX. Pada aspek mekanisme transaski pada pasar modal syariah hanya sebagian kecil yang masih meragukan kesyariahannya, karena faktor isu dan kurangnya pemahaman, faktor adanya unsur ketidakpastian naik turunnya harga saham.
\end{abstract}

Kata kunci : perilaku investor, keputusan investasi, pasar modal syariah 


\section{INTRODUCTION}

\section{Background}

The growth of the Sharia Finance industry in Indonesia well developed. The Sharia based financial concept today has been widely accepted in the world and has become an alternative for good markets that want sharia compliance (Yuliati, 2011; Ali, et.al. 2019). One of the growing Islamic financial industries in Indonesia is the Islamic capital market industry. The Capital Market Industry provides an alternative means of investment for the public to invest their funds to safeguard their assets wealth to avoid the risk of the reduced value of people's assets due to the influence of inflation, addition it can also be used to benefit from the investment results (Rethel, 2018).

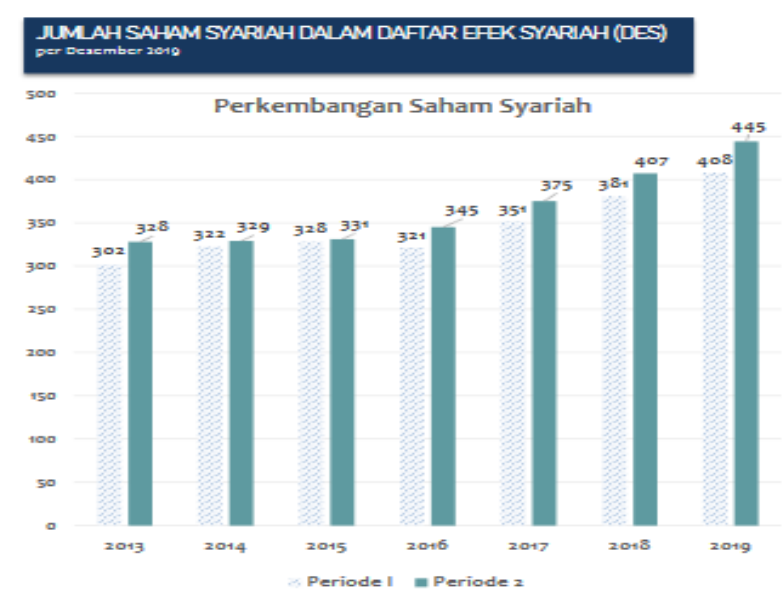

Gambar 1: Development of sharia stocks

Sources: www.ojk.go.id

The chart shows that sharia stock increase significantly from 2013 to December 2019. These indications show the development of investing, especially in companies that are guaranteed by sharia principles which have been selected by the DSN - MUI (national sharia council - Indonesian ulama council) and OJK (financial authority ) on the process, character, and companies that meet the requirements of sharia stocks called business screening and also the selection of corporate income called financial screening. According to Malik (2017) halal sharia capital market in Indonesia refers to the regulation of the financial services authority (OJK) consisting of POJK Number 15 /POJK.04/2015 on the application of sharia principles in the capital market, POJK Number 16/POJK.04/2015 concerning capital market sharia experts, POJK Number 17/POJK.04/2015 concerning issuance and requirements of sharia securities in the form of shares by sharia issuers or sharia public companies, POJK No. 18/POJK.04/2015 concerning issuance and Sukuk requirements, POJK No. 19/POJK.04/2015 concerning issuance and requirements of sharia mutual funds and POJK Number 20/POJK.04/2015 concerning issuance and requirements of sharia asset backed securities.

Sharia capital market is often considered one type of investment, where investment is investment activities, either directly or indirectly in the hope that in time the owner of the 
capital will get some profit from the investment results. Which investments are chosen and the amount of funds invested by investors is strongly influenced by the behavior of investors, namely the attitude of investors to the risks that will be faced, whether the investor likes risk (risk seeker)or avoid risk(risk averter). According to Heath and Tversky in (Wibisono, 2013), the experience factor is also one of the factors that influence the competence of investors in trading stocks. Investors who have a lot of experience in investing indicate that investors can make decisions in better transactions when compared to less experienced investors. This is because investors who have more experience will have better knowledge in dealing with certain situations that may occur and become more competent in trading stocks.

(Marsis, 2013) stated in the investment decision there needs to be consideration of return, risk and the time factor, therefore investors also need to know well from these three things to find a good investment decision as well. According to (Cahyadin and Milandari, 2009), investment decision in question is the decision to buy, sell, or maintain a shareholding. The concept of rational investors (individuals) in decision-making theory means that in making decisions, the chosen action is the action that will produce the highest utility expected (Puspitaningtyas, 2012). Rational investors will analyze the investment decision-making process. Analysis conducted among others by studying the company's financial statements, as well as evaluating the company's business performance. The goal is the investment decision taken will provide optimal satisfaction (utility).

Several empirical studies prove that investment decisions are based on several things, namely accounting information, investor perception of the company's future profits, risks faced, and investment decision-making time. Lipe (1998) in Sitinjak (2013) uses accounting information and market information in risk assessment and making investment decisions. His experimental studies tested the risk considerations and decisions of individual investors to invest influenced by variables (variants of yield and covariance of returns with market returns) and accounting risk measurement. (Hartono, 2010) stated that investment by simply calculating the return alone is not enough, the risk must also be taken into account. Risk is one of the factors of a trade-off that must be considered in an investment (the other factor is return).

Then (Shiller, 1987) in his research concluded that the actions of investors are not controlled by the psychological aspects of investors, such as fear (fear), greed (greed), and panic (madness). (Parmitasari, Hamzah, Alam \& Laba, 2018) examined the influence of investment ethics on the behavior of capital market investors and its impact on capital market investors' financial satisfaction. The research showed that investment ethics affected financial satisfaction, investment ethics also affected investor behavior. According to (Agustin \& Mawardi, 2014; Duqi \& Al-Tamimi, 2019) Islamic principles in investment activities cover at least five aspects, namely: not seeking sustenance on haraam things, not wronged and not persecuted, justice in the distribution of income, and no element of usury, maysir (gambling, speculation), and gharar (obscurity).

The behavior of Muslim investors in making investment decisions on sharia capital markets needs to be guided by the rules of muamalah in Islam. To increase the growth of the sharia capital market industry various efforts are made by Bapepam and LK to socialize the Capital Market ranging from counseling to the general public, students, students, and academic community, the participation of Bapepam and LK officials in a seminar, workshop, television interview, to the provision of information through the Bapepam and LK sites in 
http://www.bapepam.go.id. Also, various training has been given to parties related to the Capital Market (Capital Market Socialization Study Team, 2006).

The movement of investment through the purchase of shares among students looks quite squirming. Some previous studies have examined the influence and relationship between investment knowledge and income on students' interests to invest in the capital market. The results showed the influence of investment knowledge and income has a significant positive influence on students to invest in the capital market (Merawati \& Putra, 2015; Han \& Park, 2019).

Research on behavior in the field of Islamic investment among the students are limited. The reference of behavioral research in the field of Islamic financial and investment management, especially in Indonesia infrequently. By looking at this condition, behavioral studies in the field of Islamic investment are indispensable. Students as a group of people who are literate towards information, futuristic thinking, dynamic, and like new challenges have the potential to become active actors in investment in the sharia capital market by conducting sharia stock transactions. Studies and research on the behavior of Muslim student investors in investing in the capital market are still difficult to find. In this study, the authors tried to analyze in terms of the behavior of Muslim student investors in investment decision-making in the sharia capital market by conducting an interview.

\section{PROBLEM FORMULATION}

1. How investors behavior in sharia capital market?

2. How investors behavior in sharia aspects of sharia capital market?

\section{THEORITICAL BACKGROUND}

\section{Muslim Investor Behavior}

Behavior is an act of human rationality that has characteristics such as always thinking before deciding, having a preference, being able to choose the best alternative among the options available, being able to pay attention to all information, being able to evaluate and compare information, and being able to find answers based on the results of rational analysis of the information (Asri, 2013). In the book know authority the financial services industry mentioned that investment is the activity of buying financial products in the hope of getting a higher selling value and profit-sharing in the future (OJK, 2014).

In various literature, the theory of financial behavior(behavioral finance theory)can be interpreted as the application of psychological science in the discipline of financial science. Financial behavior is an analysis of investing using psychological science in financial science, which is a clear approach to how people (investors) make investments or related to finance influenced by psychological factors. (Daniel, 1998) revealed that psychological factors influence investor behavior and stock price (Agustin \& Mawardi, 2014). The courage of Muslimah investors in taking risks when investing in Sharia capital markets tends not to behave social interaction, but tends to behave emotion, familiarity and representativeness (Magdalena et al., 2019). 
There are several types of investors according to (Halim, 2005) which are associated with his preferences: investors who like risk(risk seeker), investors who are neutral to risk(riskneutral), and investors who do not like risk (risk-averse). Investors who dare to take risks (risk seekers)are divided into 3 parts, namely:

1. Those who dare to take high risks with the expectation of yields are also relatively high.

2. Those who are brave enough to risk a moderate with a yield that is also moderate.

3. Those who only dare to take risks at a relatively low level with relatively low returns.

In the concept of investment basically, all investors do not like risk(risk-averse), it is said that because no investor likes to look for risk, so the assumption is that there is a difference between investors and gamblers (Huda, Nurul \& Nasution, 2008). According to research conducted by (Tahir and Bimble, 2011) investment behavior is influenced by religious level. In Islam, investing activities include muamalah activities where the original law of muamalah activities is mubah (maybe), so investing is said to be mubah (maybe) unless there is a law on prohibitions that follow it (haram).

According to Dadan Muttaqien in Malik (2017) investment is an activity carried out by property owners (investors) to business owners (issuers) to empower business owners in carrying out their activities, where the owner of the property (investor) hopes to obtain certain benefits which financing and financial investment activities based on the same principle as other business activities that maintain the principle of idolatry and fairness. Investing using sharia norms is a science and charity, therefore, investment is highly recommended for Muslims (Al Hasyr:18).

\section{Investment Decision Making}

An individual's decision to place his funds on a particular type of investment. Assessment of investment decisions can be assessed by individual percentages and determines the number of funds invested in the capital market or money market. Investment decisions of an investor in the stock market are strongly influenced by behaviors including investor sentiment, over/under reaction, herd behavior and perception of risk (Innayah, Pratama \& Hanafi, 2020). Investment decisions relating to the selection of investment alternatives that are considered to benefit a company or individual. To achieve investment objectives, investment requires a process in decision making, so that the decision has taken into account the expectations of return obtained and also the risks that will be faced. Investment decisions are influenced by herding factors and investment experience. An experienced investor has a variety of alternatives in making investment decisions taking into account high returns (Mutawally et al., 2019). Decision on Sharia stock investment, a Muslim who belongs to a certain community considers the factors of rationality, psychology and religiosity (Amirullah, 2020)

According to (Mandal, 2013) there are stages in investment decision making that must be faced by investors, among others:

1. Determining investment policy, there is a positive relationship between the level of return and risk, then the investment objectives of investors are not only to acquire wealth but investors must also to understand that there are possible risks that could potentially cause losses. 
2. Analysis of securities, at this stage, is analyzing securities that include the valuation of securities both individually and in several groups of securities.

3. Portfolio formation, in this stage of forming a portfolio that involves identifying which assets will be the choice in the investment and determining how much investment is in each security.

4. Revise the portfolio, over time, investors may change the objectives of the initial investment, namely to form a new, more optimal portfolio.

5. Evaluation of portfolio performance, at this last stage, an investor will assess the performance of his portfolio in periodic return and risk.

\section{Sharia Capital Market}

Sharia capital market is intended to meet the interests of investors who want to base their investment activities based on sharia principles, then in several world stock exchanges have been compiled an index that specifically consists of components of stocks classified as business activities that are not contrary to sharia principles (Huda, Nurul \& Nasution, 2008:45). The National Sharia Council (DSN) together with Bapepam launched the sharia capital market with a product approach. Sharia capital market was launched in anticipation of new trends in supply and demand.

The definition of the capital market under law No. 8 of 1995 concerning Capital Market (UUPM) is an activity related to public offerings and securities trading of public companies related to the securities issued, as well as institutions and professions related to securities. Based on the definition, sharia capital market terminology can be interpreted as activities in the capital market as stipulated in the UUPM that are not contrary to sharia principles. Therefore, the sharia capital market is not a separate system from the overall capital market system. In general, sharia capital market activities have no difference with conventional capital markets, but there are some special characteristics of Sharia Capital Market, namely that products and transaction mechanisms do not conflict with sharia principles (Malik, 2017).

\section{RESEARCH METHOD}

This research uses a qualitative research approach. Qualitative research is a research method based on the philosophy of postpositivism or interpretive, used to research on the condition of natural objects, where researchers as a key instrument, data collection techniques are conducted triangulated (combined), data analysis is inductive or qualitative and qualitative research results emphasize more meaning than generalization (Sugiyono, 2018: 347). This research format is a qualitative descriptive format, as conveyed by Leksono (2013:184) that qualitative discrete format is more appropriate if used in research related to problems that require in-depth study.

The population in this study is Muslim students who conduct transactions on the sharia capital market, uses purposive sampling method. Purposive sampling was conducted based on certain characteristics that are considered to have a link with previously known population characteristics. The determination of the investor sample thirteen students are done with certain considerations, namely on the condition that the respondent is an investor who already has a Sub Securities Account (SRE), actively conducting transactions on sharia capital markets, as an active student who is studying at a university in Yogyakarta. This consideration is done in the hope that the informant can provide information that facilitates what is needed by the 
researchers. The data collection method was used in this study by conducting in-depth interviews to obtain direct responses (Soerratno \& Asyad, 2003).

The validity of qualitative research was conducted to check the accuracy of the results of the study, while the reliability of the research was conducted to ensure the approach used by researchers was consistent (Creswell, 2016: 269). Validation efforts are made by modulating different information data sources by examining the evidence that feels from the source and using it to construct coherent justifications of themes (Leksono, 2013: 174). Analisis data descriptive is used to describe the results of research in the field, especially related to research respondents, and examine in detail various things about (1) characteristics of investor demographics chosen based on respondents in the study. (2) investor behavior. (3) investors believe in sharia aspects of sharia stocks.

Qualitative data analysis is performed when empirical data obtained is qualitative data in the form of a collection of tangible words and not a series of numbers and can not be arranged in categories/classification structures. Data may be collected in a variety of ways (observations, interviews, document digests, tapes) and are usually processed first before they are ready for use (through recording, typing, editing, or instead of writing), but the qualitative analysis still uses words that are usually organized into expanded text, and do not use mathematical or statistical calculations as analytical tools. According to Miles and Huberman, analysis activities consist of three flow of activities that occur simultaneously, namely data reduction, data presentation, and conclusion /verification.

\section{RESULT AND DISCUSSION}

From interviews with several informants obtained several descriptions of their answers. Regarding the type of investor can be categorized into two: namely, dare to take risks and do not dare to take risks. The response of informants who dare to take risks (A1-4):

A1: In general indeed to gain a profit in investment, we must dare to decide to buy or release shares when the price is good".

A2: High-profit high risk. If you want to get a high profit yes must be a brave risk in stabilizing investment decisions, for example when there are stocks that have a good price and prospects, yes buy.

A3: I am one of the people who do not bother when deciding on investments, just be confident with my analysis and my experience.

A4: It has been intended investment yes, should be run, with consideration and an optimistic attitude. Yes, investments must be ready to profit and also ready to lose because of miss-predicting. But now it's a lot of information and stock analysis from experts so we as investors are helped.

The Risk-averse informant responses (B-9:

B1: I if you want to take an investment decision yes think first, consider, fear if the wrong decision, let alone the funds used for investment set aside from the pocket money sent by parents"

B2: In deciding on buying shares or releasing shares need to be considered carefully, by gathering a lot of information, the analysis of experts let me not lose. 
B3: If there are stocks that are again good value, does not immediately decide to buy, but look for accounting information, technical analysis first, sometimes discussions with the WA group that contains investors guided by the team of securities. I avoid the risk of loss with care, unfortunately, the money is the loss.

B4: I am not easy to make investment decisions in the capital market, although sharia I tend to avoid things quickly, I am among those who are not prepared to face risks.

B5: I am among the investors who are not ready to take risks, so it is better to be careful. Investments in safe stocks such as indofood shares, astra, which entered the blue-chip, but safe, anyway also get profit.

B6: I'm avoid transactions of newly listed stocks, I could not predict its performance and worried if it resulted in losses, therefore I made a decision with many considerations B7: I decided to invest carefully. My investment decisions are based on financial analysis and experience $i$ had in this field.

B8: Investment is done carefully, considering the aspects of security and halal, I also use financial analysis and other supportive analysis and supported by intuition that I have.

B9: Investing in sharia capital markets for me is a great advantage with clear and transparent information, but remain cautious in investing. I learned it before deciding, by studying the company's financial performance .

Investment contains an element of uncertainty or risk. Investors do not know the exact result of the investment they make. In such conditions, investors are said to be at risk. If the investor expects a high profit, then the investor must be prepared to bear a high risk as well. In Sharia investment, risk is not similar to uncertainty. Both are similar terms but not the same. The likeness of both lies in the understanding of an uncertain event in the future. For uncertainty terms, uncertainty refers to unexpected risks, while risks in this case are intended as something predictable (expected risk). Furthermore, the difference between the two lies in the estimate of the uncertainty. Quantitative measurement of investment risk in this case can be done in the condition that information is available.

An overconfidence investor will have confidence in making decisions and more risk when conducting stock transactions because he thinks he has abilities and skills more than anyone else. The decision to choose to place funds on stocks involves both cognitive factors and human emotions as investors. Rationally investors will choose profitable stocks taking into account the level of return and risk of those stocks. But emotional factors make investors less likely to be irrational in choosing unprofitable stocks, due to the error of analyzing and translating information against improper stock prices. Most investors invest by considering accounting information factors without considering other factors. Psychological factors contribute to investment decisions. In fact, various parties argue that this investor psychology factor has the most role in investing. In addition, investor education is the most influencing factor in individual investor decisions. According to (Tanusdjaja, 2018) in his paper highly educated investors have more knowledge of stock movements and are more courageous in taking risks so that their decision-making in investing is greater than that of lower education investors. The decision to choose to place funds on stocks involves both cognitive factors and human emotions as investors. Rationally investors will choose profitable stocks taking into account the level of return and risk of those stocks. But emotional factors make investors less likely to be irrational in choosing unprofitable stocks, due to the error of analyzing and translating information against improper stock prices. Most investors invest by considering 
accounting information factors without considering other factors. Psychological factors contribute to investment decisions. In fact, various parties argue that this investor psychology factor has the most role in investing.

In making investments investors, in general, have understood the potential benefits and risks that will be faced. The conclusion was taken by (Rahmawati, 2018) from the results of her research supports some respondents' opinions in this study where investors realize the profit result is proportional to the risk and it is reasonable and understandable. Therefore, investment players in the capital market, in general, have prepared themselves with capital, knowledge that facilitates some investors to consult on parties who have the expertise, experience in investing in sharia capital markets. The optimistic attitude of investors who are risk-takers/seekers, in general, is optimistic as conveyed by (Malik, 2017) the owner of centering security account actively conducting transactions and Optimist.

The competence of investors in the stock market reflects the existence of financial literacy that refers to understanding of how financial markets work. Investor education status broadly shows how much financial literacy the investor has. Investors with higher educational backgrounds have higher competencies, and they tend to make more frequent decisions regarding trading activities on the stock market. These findings are in line with the idea that high-quality investors will feel more competent in capital markets and tend to transact more than investors with a background in poor education.

The motive of investors to conduct transactions in the sharia capital market is to gain profit. According to (Prasetia, 2017) in his research investors in addition to looking for gain also looking for dividends. Although this research obtained differences of opinion between investors who are risk seekers and risk-averse both groups of investors understand that investment in the capital market there are opportunities for the development of funds. (Maskur, 2009) strengthens the findings of this study, namely sharia capital market provides a good opportunity for investors who are averter or who risk taker to invest in the development of funds. While the motivation variable, the indicator of statement from respondents for the increasing consideration of sharia stock purchase in Islamic Capital Market is in the hope to get the benefit of investing in sharia stocks, blessings, guaranteed good income, halal, sharia financial development, and become the owner of an invested company.

In Islam, investing activities include muamalah activities where the original law of muamalah activities is mubah (may be), so investing is said to be mubah (may be) unless there is a law on prohibitions that follow it (haram). The activity of investing in Islam by is an activity carried out by the owner of property (investor) against the business owner (issuer) to empower the business owner in carrying out his activities, where the owner of the property (investor) hopes to obtain certain benefits which financing and financial investment activities based on the same principle as other business activities that are maintaining the principle of fairness.

As for how investors believe in sharia aspects of sharia stocks, the mechanism of transaction in the sharia capital market, and the release of elements of maghrib (maysir, gharar, riba). Respondents' answers can be divided into two: sure and somewhat sure. The respondent's opinion on Islamic capital market:

$\mathrm{C} 1$ : I am convinced that the shares traded in the sharia capital market and transaction mechanism in the sharia capital market are following Islamic sharia rules. Moreover, 
in the sharia capital market there is a role of DSN, fatwa ulama also and capital market supervisor.

C2: both shares and the transaction process in the sharia capital market in Indonesia is following sharia. It has been freed from gharar, maysir also not usury. Also, there is a fatwa DSN also I learned from the books.

C3: shares traded in sharia capital market are the shares of companies that do not produce goods and services that are prohibited by religion, so the shares are already syar'I, also the transaction mechanism is regulated and supervised by the DSN, and involves Islamic economists.

C4: both shares and transactions shar'i in my opinion, I have participated in the socialization of sharia capital market. I believe it's no element that religion prohibits.

C5: sharia-compliant shares, as well as the mechanism of the transaction process. Shares traded are shares of companies that produce goods or services that are halal and transactions have been regulated following the ethics of transactions in Islam.

C6: There is no element of maghrib (gharar, maysir and usury in the transaction), the contract is clear. Also, its shares that are traded fall into the category of sharia stocks

C7: The shares sold are shares of companies that produce goods and services that are not prohibited in religion, but sometimes still doubt whether the transaction can be separated from the element of speculation, because it could be up and down the share price is not clear on what basis.

C8: The status of its shares from companies that do not violate sharia from the side (products or services produced) but the share price does not reflect real financial performance. So this is what sometimes makes doubts.

C9: Is the status of the shares syar'I is real, yes we believe. Similarly, the transaction is also following Islamic sharia, yes we are also somewhat hesitant especially if there are issues about the validity of the sharia capital market that is less shar' $i$.

C10: Yes, I think the shares traded in the capital market are fit in sharia compliant. therefore I have no doubt, moreover, it has obtained halal status from MUI.

C11: I am sure that I have followed mui fatwa regarding sharia capital market operational rules. I feel comfortable investing in sharia capital market because it is halal.

C12: Sharia capital market stocks have obtained a permit and in accordance with the MUI fatwa. It has also been endorsed by the MUI fatwa commission.

C13: It is sharia-compliant and complete, it needs digital-based product development. I believe sharia capital market can meet it.

In the study of fiqh muamalah, the term to refer to uncertainty is gharar and tadlis. It's like uncertainty and risk. Often the two words are exchanged so that it is said uncertainty and risk is gharar. Whereas both there are fundamental differences such as the discussion above is about the provision of information. In gharar the lack of information knowledge is experienced by both parties, while in tadlis only experienced by one party. The negative perception arises because of the lack of public education, namely socialization about sharia capital market, as well as their understanding of sharia capital market system. In fact, sharia capital market can be utilized by anyone regardless of ethnic background, religion, and certain races so that it can be said to have a universal (general) nature. Furthermore, halal perception arises from the majority of people who have been educated about investment in sharia capital market. investment is said to be permissible because it does not contain elements that deviate from 
Islamic teachings. This is in accordance with the research (Hana, 2018) which states that transactions in sharia capital market are halal if in accordance with the guidelines.

Respondents have a good enough confidence in the aspect of the sharia capital market. Some things that make respondents believe that the capital market by sharia is the existence of a national sharia council (DSN) that plays a role in conducting ijtihad and issuing halal fatwas, sharia supervisory boards, shares transacted in sharia capital markets are shares of companies that produce halal goods and services, in book studies and socialization about sharia capital market also explains that aspects of gharar, maysir and usury are not applied in transactions in sharia capital markets. This research is supported by research that (Hidayah, Aslicha \&Hana, 2020) which examines public perception of sharia capital market, that: education in the form of socialization about the capital market is able to build a positive perception about the halalness of sharia capital market. The role of supervisory authorities such as OJK, DSN MUI, Bapepam, and DPS is able to strengthen public perception of the halal sharia capital market. This research is in line with the findings made by (Mubarok, 2018) in his research that socialization and education to the public increase interest and trust in investment in the sharia capital market. The role of literacy, socialization, training both conducted by the authorized authorities and universities through the educational curriculum, investment trainings conducted continuously able to change the perception of the public, especially investors to doubts about the halalness of sharia capital market. Shares issued by companies whose shares are transacted in sharia capital markets need to be evaluated periodically. (Mashudi stated, 2019) that investor confidence in investing in the sharia capital market needs to be improved one of the efforts made is to evaluate sharia stocks, increase public participation in sharia capital market investment.

Nevertheless, there are some opinions of respondents that need to be underlined about the fairness and validity of fluctuations in the share price, whether the share price is a reflection of the company's performance in real terms, and also the issues that still exist in the community about aspects of sharia capital market conformity and sharia values. Respondents doubts also occurred in Mukhlis and Hutomo's research (2018) where the reputation of sharia banks is influenced by non-halal income, meaning that non-halal income can affect the reputation of sharia tires. Besides, the importance of actors and supervisors of the shari'a capital market pays attention to trading mechanisms and supervision on sharia capital markets. The existence of a complete contract, supervision on the capital market and transaction mechanisms (trading) can increase public confidence in business practices in the Islamic capital market.

The opinions of informants who still doubt the halal market for Islamic capital market in this research in line with in line with the research conducted by Hidayah, Aslicha \& Hana, (2020) the perception of haram arises because have not been educated regarding investment in the Islamic Capital Market. There are some reason behind the assumption that it is illegal, namely the existence of element of uncertainty. The uncertainty in question is regarding the sum of the gains and losses from the transaction. In addition to the lack of knowledge about sharia investment, there are still many differences of opinion among scholars regarding sharia capital market law. This is still a challenge that must be faced for Islamic economic activists, Islamic capital market authorities and academics. Through socialization activities, training and studies on Sharia investment and Islamic capital market. 
In Islam, investing activities include muamalah activities where the original law of muamalah activities is mubah (may be), so investing is said to be mubah (may be) unless there is a law on prohibitions that follow it (haram). The activity of investing in Islam by is an activity carried out by the owner of property (investor) against the business owner (issuer) to empower the business owner in carrying out his activities, where the owner of the property (investor) hopes to obtain certain benefits which financing and financial investment activities based on the same principle as other business activities that are maintaining the principle of fairness.

\section{CONCLUSSION AND SUGGESTION}

From the study conducted on the answers of respondents (informants) can be obtained an idea that basically sharia capital market investors who are among students have the character of risk-taker and risk averter. Risk-taker dares to take investment decisions without convoluted, full of confidence, understands that in every investment there is a potential failure, and believes that investments that want to earn a large profit are also faced with the risk of loss. While riskaverse tend to be careful in making investment decisions, tends to avoid investment, when going to buy or sell shares will analyze first, consult with friends or partners who have information and experience, are not prepared to lose. The risk-averse type will choose to buy stocks that have existed for a long time compared to the newly listed stocks and blue chips.

Sharia capital market investors who are the majority of students have good confidence about the validity of stocks traded in the sharia capital market. They believe in the fatwa of the cleric, the role of the DSN, and the role of the capital market supervisory body. They are mostly also looking for information about sharia capital market awareness through books, capital market socialization, IDX web. On the aspect of transaction mechanism in sharia capital market, only a small percentage still doubt its validity due to issue factors, factors of the correctness of the company's financial performance, and factors up and down the share price due to the element of speculation.

This research still has limitations in digging the depth of interviews to informants, as well as the heterogeneity of informants. Future research is expected to be developed empirical research with a larger number of respondents and from non-students.

\section{REFERENCE}

Ali, M., Raza, S. A., Puah, C. H., \& Amin, H. (2019). Consumer acceptance toward takaful in Pakistan. International Journal of Emerging Markets.

Amirullah, M. C. R. (2020). Faktor Yang Mempengaruhi Perilaku Investor Muslim Pada Komunitas Pasar Modal Syariah Dalam Keputusan Berinvestasi Saham Syariah. repository.unair.ac.id. http://repository.unair.ac.id/104334/

Cahyadin, M., \& Milandari, D. O. (2009). Analisis Efficient Market Hypothesis (EMH) di Bursa Saham Syariah, 2005: 1 â€"2008: 11. La_Riba, 3(2), 223-236.

Creswell, J. W. 2016. Research Design:Pendekatan Metode Kualitatif, Kuantitatif, dan Campuran. Edisi Keempat. Kusmini Pancasari. Pustaka Pelajar:Yogyakarta 
Duqi, A., \& Al-Tamimi, H. (2019). Factors affecting investors' decision regarding investment in Islamic Sukuk. Qualitative Research in Financial Markets.

Erna Retna Rahadjeng. (2011). Analisis Perilaku Investor Perpsektif Gender Dalam Pengambilan Keputusan Investasi di Pasar Modal, Jurnal Humanity Vol.6, No.2, Maret, 90-97

Fahmi, I. (2012). Manajemen Investasi Teori dan Soal Jawab. Salemba Empat. Jakarta.

Fauzan. M., Suhendro D. (2018). Peran Pasar Modal Syariah Dalam Mendorong Laju Pertumbuhan Ekonomi Di Indonesia, HUMAN FALAH: Volume 5. No. 1.

Halim, A. (2005). Analisis Investasi. Jakarta: PT Salemba Emban Patria

Hana, K. F. (2018). Dialektika Hukum Trading Saham Syariah di Bursa Efek Indonesia. Tawazun: Journal of Sharia Economic Law, 1(2), 148-160. Retrieved from http://journal.stainkudus.ac.id/index.php/tawazun/index

Han, K. W., \& Park, S. B. (2019). An analysis on the effects of economic conditions on investment behavior: focusing on level of finance knowledge, income-expenditure balance and liquidity constraints. International Journal of Economics and Finance, 11(11), 1-52.

Hasan, Iqbal. (2004). Analisis Data Penelitian Dengan Statistik, Bumi Kasara, Jakarta.

Hartono, Jogiyanto. (2010). Teori Portofolio dan Analisis Investasi. BPFEYogyakarta.

Hamonangan, Dapot. (2007). Pengaruh Pengetahuan Investasi Mahasiswa Jurusan Akuntansi Terhadap Minat Untuk Berinvestasi Pada Pasar Modal Di Kota Palembang. Jurnal Keuangan dan Bisnis, Vol.5 No. 2 Oktober 2007, p. 136- 147.

Hidayah, N. L., Aslicha, G., \& Hana, K. F. (2020). Persepsi Masyarakat tentang Haramnya Investasi di Pasar Modal Syariah. TAWAZUN: Journal of Sharia Economic Law, 3(1), $31-44$.

Huda, Nurul dan Mustafa Edwin Nasution. Investasi Pada Pasar Modal Syariah. Jakarta; Prenada Media, 2008.

Innayah, M. N., Pratama, B. C., \& Hanafi, M. M. (2020). The Effect of Intellectual Capital towards Firm Performance and Risk with Board Diversity as a Moderating Variable: Study in ASEAN Banking Firms. JDM (Jurnal Dinamika Manajemen), 11(1), 26-37.

Iqbal, Muhammad. (2006). Asuransi Umum Syariah dalam Praktik Upaya Menghilangkan Gharar, Maisir dan Riba, Gema Insani Pers, Jakarta

John Wiley \& Sons Bajtelsmit. (1996). Vickie L., and Alexandra Bernasek, "Why Do Women Invest Differently Than Men?" Financial Counseling and Planning, VII, 1-10 Barber, 
Koentjara. (2012). Wuryanti, Implementasi Nilai-Nilai Syariah dalam Meningkatkan Kinerja Asuransi Syariah di Jawa Tengah, FE Unisula Semarang, Jurnal Prestasi, Vol. 10. No 2. Desember

Leksono, Sonny. (2013). Penelitian Kualiatif Ilmu Ekonomi dari Metode ke Metode, Rajawali Grafindo, Jakarta

Luh Komang Merawati \& I Putu Mega Juli Semara Putra. (2015). Kemampuan Pelatihan Pasar Modal Memoderasi Pengaruh Pengetahuan Investasi Dan Penghasilan Pada Minat Berinvestasi Mahasiswa, Jurnal Ilmiah Akuntansi dan Bisnis, Vol. 10. No. 2, Juli 2015

Asri, Marwan. (2013). Keuangan Keperilakuan, Edisi Pertama, Yogyakarta: BPFEYogyakarta

Masyhudi, H. (2019). PASAR MODAL SYARIAH PERSPEKTIF HUKUM ISLAM SEBAGAI PENGUAT EKONOMI NASIONAL. MIYAH: Jurnal Studi Islam, 15(2), 290-312.

Maskur, A. (2009). Volatilitas harga saham antara saham konvensional dan syariah. Dinamika Keuangan dan Perbankan, 1(2), 82-94.

Magdalena, B., Susanti, S., \& Yanti, Y. (2019). PERILAKU INVESTOR MUSLIMAH DI PASAR MODAL SYARIAH DI LAMPUNG. Jurnal Bisnis Darmajaya, 4(1), 26-44.

Malik, A. D. (2017). Analisa faktor-faktor yang mempengaruhi minat masyarakat berinvestasi di pasar modal syariah melalui Bursa Galeri Investasi UISI. Jurnal Ekonomi dan Bisnis Islam (JEBIS), 3(1), 61-84.

Mandal, N. (2013). Sharpe's Single Index Model and its Applicarion to Construct Optimal Portfolio: an Empirical Study. Great Lakes Herald Vol. 7 No. 1, 1-34

Mansour Fakih. (1999). Menggeser Konsepsi Gender dan Transformasi Sosial, Pustaka Yogyakarta

Mubarok, F. K. (2018). Peran sosialisasi dan edukasi dalam menumbuhkan minat investasi di pasar modal syariah. INOVASI, 14(2), 113-122.

Marsis. As. (2013). Rahasia Terbesar Investasi. Second Hope. Yogyakarta (ID).

Muchlis, S., \& Utomo, H. S. (2018). Kajian Pendapatan Non Halal Dan Dampak Penggunaannya Terhadap Reputasi Dan Kepercayaan Nasabah Perbankan Syariah. JRAK: Jurnal Riset Akuntansi dan Komputerisasi Akuntansi, 9(1), 75-101.

Mutawally F.W., Asandimitra N (2019). Pengaruh financial literacy, risk perception, behavioral finance dan pengalaman investasi terhadap keputusan investasi mahasiswa Surabaya, Jurnal Ilmu Manajemen Volume 7 Nomor 4, Jurusan Manajemen Fakultas Ekonomi Universitas Negeri Surabaya. 
M. and Odean Terrance. (2001). "Boys Will Be Boys : Gender, Overconfidence, And Common Stock Investment". The Quarterly Journal of Economics 116: 261-292.

OJK. (2014). Mengenal Otoritas Jasa Keungan Dan Industri Jasa Keuangan, Kelas x, Jakarta

Puspitaningtyas, Zarah. (2010). Relevansi Nilai Informasi Akuntansi dan Manfaatnya Bagi Investor. Jember: Ekuitas: Jurnal Ekonomi dan Keuangan ISSN 1411-0393.

Parmitasari, R. D. A., Hamzah, D., Alam, S., \& Laba, A. R. (2018). Analysis of Ethics and Investor Behavior and Its Impact on Financial Satisfaction of Capital Market Investors. Scienctific Research Journal (SCIRJ), 4.

Puspitaningtyas, Z. (2012). Relevansi nilai informasi akuntansi dan manfaatnya bagi investor. EKUITAS (Jurnal Ekonomi dan Keuangan), 16(2), 164-183.

Pramita Agustin \& Imron Mawardi. (2014). Perilaku Investor Muslim Dalam Bertransaksi Saham di Pasar Modal, JESTT Vol. 1 No. 12 Desember 2014

Prasetia, Y. S. (2017). Implementasi Regulasi Pasar Modal Syariah Pada Sharia Online Trading System (SOTS). Al-Tijary, 2(2), 133-144.

Rahmawati, Y. (2018). Relevansi Nilai Pengetahuan Tentang Investasi Dan Manfaatnya Bagi Investor Kelompok Mahasiswa Febi Iain Ponorogo. ACTIVA: Jurnal Ekonomi Syariah, 1(2), 55-74.

Rethel, L. (2018). Capital market development in Southeast Asia: From speculative crisis to spectacles of financialization. Economic anthropology, 5(2), 185-197.

Shiller, R. J. (1987). Investor behavior in the October 1987 stock market crash: Survey evidence. NBER working paper, (w2446).

Soeratno \& Asryad, Lincoin. (2003). Metodologi Penelitian Untuk Ekonomi dan Bisnis, UPP AMP YKPN, Yogyakarta.

Sitinjak, E. L. M. (2013). Perilaku investor individu dalam pembuatan keputusan investasi saham: efek disposisi dan informasi akuntansi. Jurnal Organisasi dan Manajemen, 9(1), 31-53.

Sugiyono. (2017). Metode Penelitian Bisnis, Alfabeta, Bandung.

Sugiyono. (2018). Metode Statistika Untuk Penelitian. Bandung: CV Alfabeta.

Shanmugam, B., \& Zahari, R. Z. (2009). A primer on islamic finance (pp. 110e121). Research Foundation of CFA Institute.

Tahir, I., \& Brimble, M. (2011). Islamic investment behavior. International Journal of Islamic and Middle Eastern Finance and Management, Vol. 4 Iss:2, pp.116-130. 
Tanusdjaja, H. (2018). KEPUTUSAN INVESTASI INVESTOR INDIVIDU BERDASARKAN KOMPETENSI, OVERCONFIDENCE, DAN PENDIDIKAN. Jurnal Muara Ilmu Ekonomi Dan Bisnis, 2(1), 234-244.

Wibisono, O. P. (2013). Pengaruh Kompetensi dan Kepercayaan Diri Investor Terhadap Perilaku Perdagangan Saham. Journal of Business and Banking, 3(1), 47-56.

Yuliati, Lilis. (2011). Faktor-faktor Yang Mempengaruhi Minat Masyarakat Berinvestasi Sukuk, Jurnal Walisongo, Vol. 19, No.1, Mei

http://www.ojk.go.id

http://www.bapepam.go.id. 